\title{
PENDAMPINGAN MEMBANGUN PEMIMPIN HAMBA DI SEKOLAH TINGGI THEOLOGIA EBENHAEZER
}

\author{
Sri Wahyuni Kusradi $\left.{ }^{1}{ }^{*}\right)$, Marlon Butarbutar $^{2}$, Ferdinan Pasaribu $^{3}$ \\ Sekolah Tinggi Theologia Ebenhaezer ${ }^{123}$ \\ *)Email Correspondence: yunikusradi@gmail.com
}

\begin{abstract}
This article intends to describe a pattern of mentoring to shape the students of Ebenhaezer Theological Seminary (Ind. STTE) as servant leaders. This is motivated by the lack of the number of servants of God who can become a leader at the same time. There is also the view that a true leader is only born, not formed. There are many discussions about Servant Leader, but this article intends to discuss how to be mentored informing as a servant leader in the STTE. In this article, the author uses qualitative methods. To find this problem, the writer interviewed several students who were being formed in the STTE. The writer also tried to find a theoretical basis for nurturing or mentoring to form Servant Leaders and make them relevant in the formation of Theology students. Based on this evaluation, it can be seen that effective tutoring or mentoring can help students become powerful Servant leaders.

Keywords: $\quad$ Nurturing, Servant Leaders, Ebenhaezer Theological Seminary
\end{abstract}

Abstraksi: $\quad$ Artikel ini hendak memaparkan sebuah pola pendampingan untuk membentuk para mahasiswa Sekolah Tinggi Theologia Ebenhaezer (STTE) sebagai pemimpin hamba. Hal ini dilatarbelakangi oleh kurangnya jumlah hamba Tuhan yang sekaligus dapat menjadi seorang pemimpin. Juga adanya pandangan bahwa seorang pemimpin sejati hanya dilahirkan, bukan dibentuk. Ada banyak bahasan tentang Servant Leader, tetapi artikel ini membahas pendampingan dalam pembentukan sebagai seorang servant leader di STTE. Dalam tulisan ini penulis menggunakan metode kualitatif. Untuk menemukan problem tersebut penulis mewawancarai beberapa mahasiswa yang sedang dibentuk di STTE, penulis juga berusaha menemukan landasan teoritis tentang nurturing atau pendampingan untuk membentuk para Pemimpin Hamba dan merelevansikannya dalam pembentukan para mahasiswa Teologi. Berdasarkan evaluasi tersebut dapat diketahui bahwa nurtuting atau pendampingan yang dilakukan secara efektif dapat menolong para mahasiswa menjadi para pemimpin Hamba yang kuat.

Kata Kunci: Pendampingan, Pemimpin Hamba, Sekolah Tinggi Theologia Ebenhaezer

\section{PENDAHULUAN}

Dalam sebuah penelitian Roland G. Kuhl meneliti 62 Seminari Injili mendapati masalah kurangnya kepemimpinan pastoral, karena sekalipun mereka orang-orang hebat tetapi ternyata mereka bukanlah seorang pemimpin. ${ }^{1}$

1 Roland G. Kuhl, "What is Pastoral Leadership? A Review of the Relevant Literature on Approaches and Understandings of Pastoral Leadership at the Beginning of the 21stCentury." (Grand 
Sebagaimana dikutip oleh Sonny Zaluchu yang tidak setuju tentang adanya sebuah mitos bahwa seorang pemimpin itu hanyalah dilahirkan bukan dibentuk, sehingga menjadi seorang pemimpin hanyalah faktor genetik semata. ${ }^{2}$ Hal ini menjadi sebuah keprihatinan sekaligus sebuah tantangan bagi Sekolah-Sekolah Teologi (STT) untuk membentuk para pemimpin yang kuat.

Apakah bisa membentuk seorang pemimpin yang kuat melalui sebuah pendampingan bagi seorang yang secara genetik tidak dilahirkan dalam gen pemimpin? Berikut adalah kasus yang ditemukan yaitu beberapa mahasiswa merasa tidak memiliki karunia untuk memimpin tetapi dituntut untuk menjadi seorang pemimpin di tempat pelayanan praktek satu tahun. ${ }^{3}$ Hal seperti ini menjadi sebuah tantangan bagi STT sebagai sebuah institusi untuk membentuk para pemimpin hamba. Tugas Sekolah Teologi untuk mempersiapkan para calon pemimpin akan menjadi lebih mudah jika mahasiswa sudah memiliki gen pemimpin, tetapi akan diperlukan perhatian atau pendampingan khusus untuk mempersiapkan para pemimpin hamba yang tangguh. Dalam mencapai tujuan pembentukan pemimpin hamba tersebut, maka para mahasiswa memerlukan bentuk perhatian, pendidikan dan pendampingan, sehingga dalam latar belakang Kepemimpinan dalam Cara Pandang Kristen," sonnyelizaluchu.wordpress.com, Sonny Eli Zaluchu, 18 Februari 2011, https://sonnyelizaluchu.wordpress.com/2011/02/18/kepemimpinan-hamba/.

3 Danar Lukito dkk., Wawancara Apakah bisa membentuk seorang pemimpin yang kuat melalui sebuah pendampingan bagi seorang yang secara genetik tidak dilahirkan dalam gen pemimpin?, Sekolah Tinggi Theologia Ebenhaezer, 18 Desember 2020. 
masing-masing mahasiswa diperlengkapi untuk menjadi pemimpin pelayan yang baik. $^{4}$

Banyak tulisan tentang pemimpin hamba, walaupun konsep ini sesuatu yang khas dalam Perjanjian Baru, tetapi ternyata hal ini juga sudah banyak diadopsi dalam kepemimpinan sekuler dan kepemimpinan non Kristen, seperti artikel yang ditulis oleh Subhan Ajrin Sudirman tentang servant leadership, pengaruh dan kinerja pimpinan. ${ }^{5}$ Juga kepemimpinan hamba yang diambil dalam segi bisnis management ${ }^{6}$ dan banyak jurnal teologi dari dalam dan luar negeri tentang Servant Leader, tetapi fokus tulisan ini tentang bagaimana pendampingan dapat membentuk seorang pemimpin hamba? Tulisan tentang nurturing atau pendampingan juga sudah ada yang menuliskannya, sebagian besar ditulis dalam arah nurturing pemimpin dalam bidang bisnis. ${ }^{7}$ Ada satu jurnal yang membahas tentang nurturing yang sangat baik tetapi berfokus kepada pembentukan dalam sistem kepemimpinan gereja, bukan tentang bagaimana membentuk pemimpin hamba di Sekolah Teologi. ${ }^{8}$ Sehingga masih sedikit tulisan tentang pendampingan untuk membentuk seorang pemimpin hamba. Karena itu perlu menuliskan tentang pola pendampingan yang dilakukan oleh STTE sehingga mahasiswa yang tidak dilahirkan sebagai pemimpinpun dapat dibentuk untuk menjadi pemimpin Hamba.

4 Kristina Lizardy-Hajbi, "Nurturing Leadership Development for the Now and the Next: A Denominational Perspective," Reflective Practice: Formation And Supervision In Ministry 38, no. 1 (2018): 25-38, https://journals.sfu.ca/rpfs/index.php/rpfs/article/view/515/498.

5 Subhan Ajrin Sudirman, "Pengaruh Spiritualitas Terhadap Servant Leadership Dan Kinerja Pimpinan," Journal Psikologi Islam Al-Qalb Vol 8, No (2017). https://doi.org/10.15548/alqalb.v8i2.878

6 Meily Margaretha, "Pengaruh Servant Leadership, Organizational Citizenship Behavior, Kecocokan Orang-Organisasi Serta Identifikasi Organisasi (Studi Pada Organisasi Kemahasiswaan Di Lingkungan Universitas Kristen Maranatha," Jurnal Manajemen Univ. Maranatha Vol.12, No (2012). https://doi.org/10.28932/jmm.v12i1.173

7 N N, "Nurturing Leadership Qualities," www.inspiring.uk.com, Inspiring Bussines performance, 9 Mei 2016, https://www.inspiring.uk.com/nurturing-leadership-qualities/.

8 Lesley Anne Cyril, "Nurturing Servant Leaders In Religious Education: A Case Study Of The Church Educational System Of The Church Of Jesus Christ Of Latter-Day Saints In Aotearoa/New Zealand" (Auckland University of Technology, 2006). https://www.researchgate.net/publication/30040483_Nurturing_servant_leaders_in_religious_education 


\section{METODE}

Penulis menggunakan metode penelitian kualitatif dalam jenis studi kasus. Dalam hal mana hal ini peneliti menyelidiki dengan cermat tentang program, individu, peristiwa, proses ataupun aktivitas. Kasus-kasus yang diteliti ada dalam waktu dan aktifitas tertentu. Informasi dikumpulkan dengan cermat dan lengkap dengan menggunakan prosedur pengumpulan data. ${ }^{9}$ Penulis berupaya memaparkan dan menjabarkan temuan-temuan tentang problem ketersediaan pemimpin hamba dan bagaimana dalam pendampingan. Penulis adalah pengukur, di mana penulis akan menyajikan data-data berupa deskripsi. Tujuan dari deskripsi penelitian tersebut adalah untuk menjelaskan tentang apa yang dialami oleh para calon pemimpin yang tidak memiliki gen pemimpin dan bagaimana proses pendampingan dapat diberlangsungkan untuk mempersiapkan mereka menjadi pemimpin hamba yang tangguh. Penulis telah mewawancarai para mahasiswa yang dibentuk di STTE, Tanjung Enim, Sumatera Selatan. Para mahasiswa yang diwawancarai adalah mahasiswa semester akhir yang telah melewati masa praktek satu tahun dan mahasiswa yang sedang praktek satu tahun serta melayani di gereja maupun lembaga-lembaga pelayanan. Penulis melakukan observasi kepada mahasiswa. Sebagai trianggulasi penulis telah mewawancarai para mentor dan lembaga-lembaga yang terkait dalam pelayanan praktek mahasiswa tersebut, serta telah meneliti data-data dari beragam literatur tentang pendampingan dan tentang kepemimpinan hamba. Survei ini hendak menyelidiki apakah pendampingan cukup signifikan sebagai sarana untuk membentuk

9 J.W. Creswell, Research design: pendekatan kualitatif, kuantitatif, dan mixed (Yogyakarta: PT Pustaka Pelajar, 2010), $\mathrm{x}$. 
mahasiswa menjadi pemimpin hamba sekalipun mereka secara genetik tidak dilahirkan sebagai pemimpin.

\section{HASIL}

Tujuan dari pembentukan dan pendampingan yang dilakukan kepada para mahasiswa adalah untuk mempersiapkan mereka sebagai para pemimpin hamba. Maka perlu dijelaskan terlebih dahulu apa pengertian pemimpin hamba dan bagaimana karakteristik seorang pemimpin hamba. Kepemimpinan yang melayani mengacu pada filosofi kepemimpinan yang menempatkan melayani orang lain sebagai prioritas utama. Ini membutuhkan pendekatan holistik untuk bekerja, rasa komunitas dan berbagi kekuasaan dalam pengambilan keputusan. Menurut New York Times, kepemimpinan yang melayani berurusan dengan realitas kekuasaan dalam kehidupan sehari-hari, legitimasinya, batasan etisnya dan hasil bermanfaat yang dapat dicapai melalui penggunaan kekuasaan yang tepat.$^{10}$

Penelitian ini menyatakan bahwa kepemimpinan hamba bermula dari Tuhan Yesus sendiri. Nsiah dalam journal kepemimpinan menyatakan bahwa kepemimpinan hamba nampak dalam kepeimpinana Kristus, pertama, Matius 9: 2 Ini adalah salah satu kualitas atau keterampilan terpenting yang harus dimiliki seorang pemimpin. Tanpa visi, kemajuan dan perkembangan akan terhambat. Kedua, Matius 9: 4, Yesus menunjukkan kecerdasan antarpribadi. kasih-Nya yang tidak berpihak pada semua. Ketiga. dalam Matius 6: 5-14, Yesus menjadi teladan sebagai seorang guru. Dia mengajari murid-muridnya cara berdoa. Pemimpin harus memiliki keterampilan mengajar. Keempat. model lain dari kepemimpinan Kristus digambarkan dalam Yohanes 2: 1-11 yang menyatakan Kristus adalah

10 Gabriel Kofi Boahen Nsiah, "Leading as Jesus Led: Christ Models of Leadership," Open Journal of Leadership 02, no. 04 (2013): 103-5, https://doi.org/10.4236/ojl.2013.24016. 
sumber. Kelima, belas kasihan Yesus juga menunjukkan karakter yang unik Yohanes 5: 5. Keenam, dalam Matius 10, Kristus mendelegasikan tanggung jawab kepada murid-muridnya. Ketujuh, ciri kepemimpinan lain yang Yesus tunjukkan adalah doa dan keterampilannya dalam mengatasi masalah, terutama dalam situasi sulit. Kedelapan, memiliki tujuan, Kristus melewati semua pencobaan karena tujuan lebih besar dari perasaan. Seorang pemimpin perlu bekerja untuk kepentingan orang lain. Para pemimpin belajar mencari Tuhan terlebih dahulu agar menemukan kebijaksanaan (Mat. 6: 3). ${ }^{11}$ Hasil penelitian ini menunjukkan pentingnya karakteristik pemimpin. De Pree menuliskan duabelas karakteristik kepemimpinan yaitu, integritas, kerentanan, kearifan, kesadaran akan jiwa manusia, keberanian dalam hubungan, selera humor, energi intelektual dan keingintahuan, menghormati masa depan, menghargai masa kini, memahami masa lalu; prediktabilitas, luasnya, kenyamanan dengan ambiguitas dan kehadiran serta kepemimpinan sebagai posisi pelayanan ${ }^{12}$

Penelitian ini menemukan bahwa Sekolah Teologi adalah sekolah kepemimpinan yang mempengaruhi pelayanan gerejawi. ${ }^{13}$ Sekolah Teologi perlu mempersiapkan para pemimpin hamba. Melalui penelitian ini telah dibahas bahwa seorang pemimpin selain dilahirkan sebagai pemimpin, juga bisa dibentuk. Seseorang memerlukan pendampingan sebagai sebuah pola pembentukan yang dilakukan di Sekolah Teologi, mendidik para mahasiswa untuk menjadi pemimpin hamba. Hasil penelitian menemukan konsep dan pola pembentukan mahasiswa

\footnotetext{
11 Nsiah.

12 Adam Focht dan Michael Ponton, "Identifying primary characteristics of servant leadership: Delphi study," International Journal of Leadership Studies 9, no. 1 (2015), https://citeseerx.ist.psu.edu/viewdoc/download?doi=10.1.1.675.4155\&rep=rep1\&type=pdf.

${ }^{13}$ Robert S Thompson, "The perception of servant leadership characteristics and job satisfaction in a church-related college" (Disertasi, Indiana, Christian universities and colleges., 2015), http://scholars.indstate.edu/handle/10484/8123.
} 
teologi sebagai pemimpin hamba. Pertama, pemimpin Hamba adalah pemimpin yang melayani dan menjadi teladan bagi orang yang dipimpinnya. Aisiah mendefinisikan bahwa pemimpin hamba adalah seorang pemimpin sekaligus hamba. Sedangkan Selamat Tua menyatakan pemimpin hamba adalah seorang yang memberi pengaruh positif kepada orang yang dipimpin dan kepemimpinan adalah melayani. Rosana menyatakan kepemimpinan hamba terlihat dalam kepribadian seorang pemimpin yang layak untuk dihormati tetapi berkarakter yang rendah hati. Wince berpendapat pemimpin hamba bukanlah seorang pemimpin yang nge-bos tetapi yang mau terjun langsung dalam melakukan tugastugas sehingga dapat diikuti oleh para pengikut. Menurut Rani pemimpin hamba menjadi teladan dalam kelakuan maupun karakternya. ${ }^{14}$

Kedua, sebelum dibentuk di STTE sebagian besar mahasiswa tidak memiliki kemapuan menjadi pemimpin yang melayani. Benaso mengatakan baru mulai bisa memimpin sejak semester tiga dan semakin berkembang saat menjadi ketua asrama. Semangat Gea juga merasa belum memiliki kemampuan menjadi seorang pemimpin, hingga saat memasuki semester tiga ketika dipercayakan tugas sebagai ketua tingkat. Arnit sudah bisa memimpin sejak duduk di Sekolah Menengah Atas (SMA) karena telah dididik oleh ayah yang seorang pemimpin gereja. ${ }^{15}$ Fati bisa menjadi seorang pemimpin saat paraktek satu tahun, ketika dituntut untuk bisa memprioritaskan orang lain. Rani menyadari kemampuan memimpin sejak masuk STTE, saat dipercayakan untuk mengajar Sekolah Minggu (SM) dan mengajar di Sekolah Dasar (SD). Fenianus menjawab bahwa

\footnotetext{
14 Aisiah dkk., Wawancara: Pemimpin Yang Melayani Dan Menjadi Teladan Bagi Orang Yang Dipimpinnya, Video Call, 30 Januari 2021.

15 Benazo, Semangat Gea, dan Arnit Daeli, Wawancara: Sebelum Dibentuk Di STTE Sebagian Besar Mahasiswa Tidak Memiliki Kemapuan Menjadi Pemimpin Yang Melayani, Sekolah Tinggi Theologia Ebenhaezer, 30 Januari 2021.
} 
sebelum di STTE adalah seorang pemalu dan tidak tegas sehingga merasa tidak bisa memimpin. ${ }^{16}$ Benazo juga bahwa sebelumnya ia bukan seorang yang rendah hati dan tidak bisa menguasai diri. ${ }^{17}$

Ketiga, evaluasi dari para stakeholder atau lembaga dimana para mahasiswa melayani. Sebagai konfirmasi maka penulis mewawancari mentor Benaso, yaitu ibu Sembiring di Majelis Perwakilan Daerah YPPII di Pematang Siantar. Beliau menyatakan bahwa Benazo bisa menjadi pemimpin yang memberi teladan, bisa mengorganisir orang-orang yang dilayani dan rendah hati. ${ }^{18}$ Menurut Febriaman Harefa sebagai bapak Asrama menyampaikan bahwa Rani memiliki kemampuan memimpin dan bisa menjadi teladan yang baik, sekalipun sebelumnya sangat pemalu. ${ }^{19}$ Pdt. Riris Simorangkir Di Gereja Methodist Indonesia (GMI) Bahtera Bandung Timur adalah mentor Fati menyatakan bahwa kurang lebih hampir 6 bulan sudah kelihatan jiwa kepemimpinan hamba dalam memimpin pelayan. Fati dapat membina hubungan baik dengan mentor, majelis dan seluruh jemaat yg dilayani serta menunjukkan sikap rendah hati, siap dibentuk, siap berubah, displin baik dalam doa dan membaca Firman Tuhan. ${ }^{20}$

Penelitian ini menghasilkan beberapa point penting penyebab yang mempengaruhi terbentuknya kepemimpinan hamba bagi Mahasiswa Teologi. Pertama, melihat teladan para dosen, pembina unit, bapak ibu asrama dan ketuaketua asrama dan para senior. Dalam hal ini Sandro menjawab bahwa

16 Fati, Wawancara: Sebelum Dibentuk Di STTE Sebagian Besar Mahasiswa Tidak Memiliki Kemapuan Menjadi Pemimpin Yang Melayani, Video Call, 30 Januari 2021.

17 Benazo, Wawancara: Sebelum Dibentuk Di STTE Sebagian Besar Mahasiswa Tidak Memiliki Kemapuan Menjadi Pemimpin Yang Melayani, Sekolah Tinggi Theologia Ebenhaezer, 30 Januari 2021.

18 Sibarani, Wawancara: Evaluasi Dari Para Stakeholder Atau Lembaga Dimana Para Mahasiswa Melayani, Pematang Siantar, 2 Februari 2021.

19 Febriaman Lalaziduhu Harefa, Wawancara: Evaluasi Dari Para Stakeholder Atau Lembaga Dimana Para Mahasiswa Melayani, Sekolah Tinggi Theologia Ebenhaezer, 2 Februari 2021.

20 Riris Simorangkir, Wawancara: Evaluasi Dari Para Stakeholder Atau Lembaga Dimana Para Mahasiswa Melayani, Bandung, 2 Januari 2021. 
memperhatikan para dosen dan para senior bagaimana berespon terhadap masalah, cara bicaranya, bagaimana menempatkan diri saat di kelas sebagai dosen dan bagaimana di luar kelas menjadi orang tua bagi setiap mahasiswa. Arnit menjawab belajar dari ayah yang adalah seorang hamba Tuhan. Leta menjawab bahwa STTE memberlakukan pembinaan secara berlapis-lapis mulai dari pendampingan dan teladan dari kakak kamar, ketua unit, ketua asrama, bapak ibu asrama, bapak ibu unit dan bapak ibu Dosen. Ia memperhatikan bagaimana pembagian tugas, menolong mengatasi masalah, mendengarkan dan membantu mengerjakan banyak hal. Fati menjawab bahwa para pembina memberi teladan yang praktis tanpa banyak berteori tetapi mengerjakan apa yang diajarkannya.

Kedua, sejak mengalami pemulihan. Thea Ponalya menyatakan bahwa sebelum dilayani pribadi untuk pemulihan relasi dengan Tuhan, sesama dan diri sendiri, Pnalya merasa tidak layak untuk melayani atau memimpin orang lain karena masih ada luka batin terhadap keluarganya, tidak menerima diri dan merasa berdosa. Tetapi setelah dipulihkan Ponalya merasa merdeka, merasa dikasihi sehingga memiliki kerinduan untuk mengasihi sesama. Inape menyatakan bahwa sebelum mengalami Tuhan, merasa tidak bisa melakukan apa-apa yang berarti, tidak memiliki penghargaan terhadap diri sendiri, tidak berani memiliki relasi dengan sesama, tetapi setelah mengalami pemulihan di dalam Kristus, Inape berani memimpin dan merasa dilayakkan untuk menjadi seorang pemimpin. Fati menyatakan bahwa saat sebelum ada pemulihan relasi kepada Tuhan, memiliki halangan untuk melayani karena masih ada luka-luka masa lalu, tetapi setelah dilayani memiliki kemerdekaan untuk bisa melayani. 
Ketiga, belajar peka terhadap kehendak Tuhan. Rani menyatakan bahwa belajar untuk bisa menjawab dengan tepat, melalui belajar di kelas, melakukan presentasi dan diskusi di kelas. $^{21}$ Leta mengaku bahwa diajar untuk bisa memanfaatkan waktu dengan benar, datang tepat waktu, tidak terlambat mengumpulkan tugas. Selanjutnya Leta menyatakan bahwa peraturan-peraturan, sanksi-sanksi atas pelanggaran dan renungan-renungan membuat dia mengerti bagaimana harus bersikap dengan tepat dalam mengambil keputusan. Inape mengaku bahwa firman Tuhan dan buku-buku bacaan mengasah pikiran untuk bisa berfikir dengan baik dan tepat. Pinsen menyatakan bahwa motivas- motivasi dan dukungan dalam lingkungan asrama dan pelayanan membantunya bisa lebih bijaksana.

Keempat, sejak semakin banyak pengajaran-pengajaran yang didapatkan di STTE. Selamat Tua menyatakan bahwa iman dan pengajaran-pengajaran mempengaruhi cara berfikir dan cara memandang sebuah masalah. Sandro menyatakan hal yang sama bahwa sistem doktrin sangat memempengaruhi bagaimana menyikapi sebuah masalah dan tantangan sesuai dengan cara berfikir Tuhan, tidak mengikuti keinginan diri sendiri. Lidia mengaku bahwa doktrin tentang Allah, keselamatan dan kasih membentuk menjadi rendah hati dan setia dalam tugas pelayanan. Otto menyatakan bahwa doktrin-doktrin yang diajarkan menjadi arahan dalam pengambilan keputusan untuk menjadi hamba seperti Kristus yang rela berkorban.

Kelima, pengalaman hidup selama dibentuk di STTE. Inape menyatakan bahwa memiliki pengalaman tentang ketegasan kakak-kakak tingkat yang 
membuatnya memiliki ketegasan yang sama. Thea Ponalya menyatakan bahwa pengalaman di asrama berbagi bersama adik tingkat yang dalam kekurangan dan perhatian para dosen yang dalam kesederhanaan tetap mau memperhatikan kebutuhan mahasiswa merupakan pengalaman yang perlu diteladani. Mareti mengalami kesulitan saat menjadi ketua asrama karena harus menjadi teladan dan kadang apa yang dilakukan tidak selalu mendapat apresiasi, pengalaman itu justru memfokuskan kepada teladan Kristus. ${ }^{22}$

Keenam, pengembangan talenta. Wince mengungkapkan bahwa dirinya memiliki suara kecil seperti anak-anak dan merasa bahwa itu adalah sebuah kelemahan. Tetapi setelah dilibatkan dalam pelayanan life streaming dalam acara panggung boneka, dirinya baru menyadari bahwa itulah kelebihan yang Tuhan karuniakan kepadanya. Mekar menyatakan bahwa belum memiliki talenta mengajar anak-anak, tetapi setelah dilibatkan dalam pelayanan sekolah minggu, talenta mengajar anak-anak semakin berkembang.

Ketujuh, mendapatkan kasih dan kepedulian. Ani Situmorang menyatakan bahwa merasa dikasihi oleh Tuhan dan para dosen serta teman-teman membuat dirinya merasa berarti dan percaya diri untuk mengasihi orang lain juga. Fati menyatakan bahwa mendapatkan kasih sayang bapak ibu pembina unit seperti dari orang tua kandung dan itu membuat dirinya semakin ditumbuhkan kasih akan sesama. Leta mengaku bahwa mendpatkan kasih yang besar dari bapak ibu dosen dengan berbagai macam perhatian, sehingga merasa penuh dengan kasih.

Kedelapan, sejak belajar bermacam-macam skill. Rani menyatakan bahwa ia belajar menggunakan Information Technology (IT) sehingga bias membuat 
presentasi lebih baik, belajar dan berlatih mengkonseling orang lain, belajar musik, belajar khotbah yang memperlengkapi dalam pelayanan. Leta juga menyatakan bahwa di STTE belajar banyak hal praktis yang membentuk untuk selalu siap ditempatkan di mana saja. ${ }^{23}$

\section{PEMBAHASAN}

Memperhatikan hasil di atas maka perlu dibahas tentang bagaimana pendampingan dapat membentuk para mahasiswa teologi menjadi para pemimpin hamba. Pertama, memberikan pengertian tentang pemimpin hamba membuat mahasiswa akan menghidupi panggilan sebagai pemimpin hamba. Beberapa hasil wawancara di atas menunjukkan bahwa para mahasiswa yang sedang dibentuk di STTE sudah memiliki pemahaman tentang pengertian pemimpin hamba. Kesimpulan pemahaman tengan pemimpin hamba adalah seorang pemimpin yang rendah hati, menjadi teladan dan mau melayani bekerja bersama dengan orangorang yang dipimpinnya. Konsep dasar tentang pemimpin hamba telah dinyatakan dalam Alkitab oleh Tuhan Yesus Kristus sebagai Pemimpin Hamba yang sejati dan sempurna. Sebagaimana disebutkan dalam Matius 20: 28 dan Markus 10: 45 di mana kedatangan Kristus ke dunia ini adalah bukan untuk dilayani melainkan untuk melayani dan memberikan nyawa-Nya untuk menebus dosa banyak orang. Definisi pemimpin hamba dalam hubungannya dengan manusia adalah sebuah pertanggungjawaban kepada Tuhan dalam hal kepemimpinan selalu bertujuan untuk perluasan kerajaan Allah, secara intrinsik menyertakan pemahaman sifat dan konstitusi umat Tuhan.

23 Wince dkk., Wawancara: Belajar Bermacam-macam Skill, Sekolah Tinggi Theologia Ebenhaezer, 30 Januari 2021. 
Seorang Pemimpin hamba memiliki hak istimewa di mana gaya hidup, sikap, motif dan tindakan orang percaya terhadap orang lain diatur oleh keyakinan mendasar bahwa dia adalah hamba Tuhan, segala kepemilikan dari jabatan sebagai pemimpin adalah sebuah pelayanan kepada orang lain perlu diberikan dalam semangat kewajiban kepada kehendak Tuhan dan demi kebaikan terbesar dari individu-individu. ${ }^{24}$ Pemimpin hamba adalah seorang yang tangguh karena sebagai wakil Allah di bumi, memiliki kuasa dan karunia-karunia yang diperlengkapi oleh Allah untuk menjalankan tugas-tugasnya dan memiliki hak hidup sebagai alat Tuhan untuk perluasan kerajaan-Nya. Filipi 2: 4, Galatia 6: 2, 10 dan Imamat 19: 18 memberikan dasar bagaimana kepemimpinan hamba adalah kepemimpinan yang mengasihi dan memprioritaskan kemajuan orang lain serta tidak menganggap rendah sesama yang dipimpinnya. ${ }^{25}$

Kedua, membuat evaluasi dari lembaga-lembaga dimana mahasiswa melayani. Evaluasi penting untuk mengukur keberhasilan pembentukan dan pendampingan. Dalam hal ini dapat membangun komunikasi dengan mahasiswa binaan, pihak terkait dan institusi. Evaluasi juga dapat memperbaiki kekurangankekurangan dan meningkatkan prestasi yang sudah dicapai.

Ketiga, pola pendampingan. Dalam beberapa hasil wawancara di atas diketahui bahwa tidak semua mahasiswa memiliki kemampuan alamiah sebagai pemimpin. Mereka baru memiliki kemampuan memimpin saat mereka dibentuk di STTE. Mereka memperoleh pendampingan selama belajar di institusi ini. Pendampingan yang dimaksud di sini adalah berpadanan dengan kata "nurturing".

${ }^{24}$ Christopher J Newton, "Towards a Theology of Servanthood," Phoenix, University of January (2016). https://www.researchgate.net/publication/303971273_Towards_a_Theology_of_Servanthood

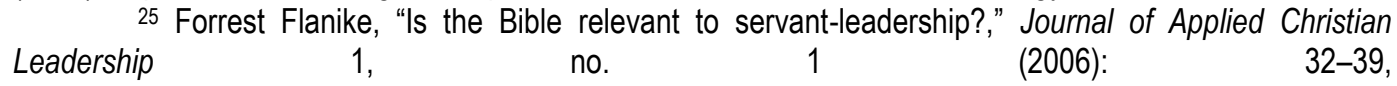
https://digitalcommons.andrews.edu/cgi/viewcontent.cgi?article=1002\&context=jacl. 
Menurut kamus Oxford arti kata nurturing masih berkaitan dengan "nurseries" yaitu mengasuh seseorang / sesuatu untuk merawat dan melindungi seseorang / sesuatu saat mereka tumbuh dan berkembang. Jika itu diterapkan dalam konteks tanaman dapat diartikan sebagai memupuk sesuatu untuk membantu seseorang / sesuatu untuk berkembang atau sukses. Nurture dalam konteks pembinaan adalah memelihara sesuatu untuk memiliki perasaan, ide, rencana dan untuk waktu yang lama serta mendorong untuk berkembang. ${ }^{26}$ Sehingga dalam membentuk seorang pemimpin hamba diperlukan sebuah nurture. Greenleaf menyatakan nurturing sebagai "pengasuhan jiwa manusia" dan "memberi makan atau memelihara, membesarkan, melatih, mendidik. Dalam memelihara ikatan hubungan diciptakan dan peluang untuk produktivitas konstruktif di masa depan meningkat. ${ }^{27}$

Pendampingan atau nurturing ini juga telah dilaksanakan pada masa PL, pada masa teokrasi berlangsung di Israel, para nabi memiliki tugas untuk mendampingi para raja dan para pegawai istana. Mereka menyampaikan nasihat kemiliteran, menyampaikan tegoran ataupun berkat. Mereka adalah Natan, Elia, elisa, Mikha, Yesaya. ${ }^{28}$ Menurut Petrus Octavianus dalam pengantar bukunya tentang Alih Generasi Kepemimpinan menyebutkan bahwa keberhasilan alih generasi dilandaskan pada tiga prinsip yaitu prinsip iman dan imani, prinsip ilmu management yang tepat dan prinsip strategi. ${ }^{29}$

Dalam hasil wawancara di atas ada beberapa hal yang mempengaruhi hidup sebagai seorang pemimpin hamba, yang terlihat dalam beberapa hal.

${ }^{26} \mathrm{~N} \mathrm{~N}$, "Nurture," www.oxfordlearnersdictionaries.com, Oxford Learners Dictionaries, diakses 27 April 2021, https://www.oxfordlearnersdictionaries.com/definition/english/nurture_1,\%20nurture,\%20t.t.

${ }_{27}$ Lesley Anne Cyril, "Nurturing Servant Leaders In Religious Education: A Case Study Of The Church Educational System Of The Church Of Jesus Christ Of Latter-Day Saints In Aotearoa/New Zealand" (Auckland, Auckland University of Technology, 2006), https://core.ac.uk/download/pdf/56361157.pdf.

${ }^{28}$ Andrew E. \& John H Walton Hilton, Survei Perjanjian Lama (Malang: Gandum Mas, 2000), X.

${ }^{29}$ Petrus Octavianus, Alih Generasi dan kepemimpinan dalam garis Firman Allah (Batu, Jawa Timur: Petrus Octavianus Institute, t.t.), $x$. 
Pertama, perlu keteladanan dari dosen maupun para senior. Hasil wawancara di atas nampak sekali bahwa pengaruh keteladanan dari para dosen, pembina, kakak tingkat, kakak kamar di asrama sangat kuat dalam pembentukan kepemimpinan hamba dalam hidup mereka. Pembimbing sebagai contoh dalam pembentukan seorang pemimpin hamba perlu memiliki fokus model yang menjadi teladan utama dalam hidup para pemimpin yaitu Tuhan Yesus, kehidupan berpusat pada Kristus sebagaimana dinyatakan dalam Filipi 1: 21-22 bahwa hidup adalah Kristus dan kehidupan di dunia ini adalah kehidupan yang menghasilkan buah. Octavianus menuliskan bahwa dalam kepemimpinan Kristen, kepribadian dan kerohanian pemimpin adalah syarat yang akan menentukan keberhasilan kepemimpinan. Selanjutnya Octavianus mengutip pendapat Stephen R. Covey yang menjelaskan bahwa prinsip pemimpin adalah menyadari bahwa pertumbuhan itu dari dalam keluar, berfokus pada perubahan diri sendiri dan kemudian mengintegrasikan prinsip-prinsip yang benar dalam cara yang selaras. ${ }^{30}$ Para pembina adalah orang-orang yang memiliki kualifikasi pengajaran yang sehat dan memiliki pendekatan mengajar dengan tepat. Dalam Perjanjian Lama Para imam dan nabi Israel dipilih oleh Tuhan dengan memiliki kualifikasi tertentu yaitu legasi dari Allah, pengetahuan akan taurat Tuhan dan kemampuan mengajar yang baik sebagaimana tertulis dalam Mazmur 78: 1 dan 2Timotius 3: 10 . Integritas pengajaran terlihat dalam relationship pembina dengan keluarga, diri sendiri dan sesama. Sehingga integritas tersebut membuat para pembina menjadi pribadi yang tangguh dan dapat menjadi figur yang berpengaruh terhadap yang dibina.

30 Petrus Octavianus, $\mathrm{x}$. 
Kedua, perlu melakukan pelayanan pribadi. Beberapa kendala yang dihadapi oleh para mahasiswa yang disampaikan dalam wawancara di atas adalah karakter yang lemah, tidak percaya diri, pemalu, pendendam dan sakit hati sehingga mereka tidak memiliki keberanian untuk memimpin. Karena karakter yang nampak dalam seorang pemimpin hamba adalah listening, empathy, healing, awareness, persuasion, conceptualization, foresight, stewardship, commitment to the growth of people, and building community. ${ }^{31}$ Maka hal pertama yang harus dilakukan dalam pendampingan adalah pembimbingan terhadap pemulihan relasi kepada Tuhan melalui kelahiran baru dan pertobatan, kepada sesama melalui pengampunan dan pemulihan relasi diri melalui penerimaan diri. Hal ini memerlukan pelayanan pribadi yang dilakukan oleh para dosen dan pembina mahasiswa. Dalam Kejadian 3 bahwa sejak manusia jatuh dalam dosa maka relasi antara manusia dengan Allah, sesama dan diri sendiri menjadi rusak, serta karakter dosa menguasai. Seorang pemimpin dapat memiliki karakter jika telah dimerdekakan dari segala jenis belenggu kepahitan dan dosa-dosa. Pemulihan relasi dapat terjadi saat seseorang menerima pengampunan Tuhan Yesus.

Ketiga, memerlukan pembentukan intuitif. Hasil wawancara di atas menyatakan bahwa proses pembentukan intuisi yang didapat dalam ruang kelas, pergaulan dengan teman-teman di asrama, peraturan-peraturan yang ditetapkan, kedekatannya dengan dosen dan kedekatannya dengan firman, pergumulan dan perenungannya dengan Tuhan akan sangat mempengaruhi kecerdasan berfikir maupun hikmat dalam setiap pengambilan keputusan. Kehidupan seorang pemimpin adalah kehidupan yang mempengaruhi orang lain, maka setiap

31 Larry C Spears, "Character and servant leadership: Ten characteristics of effective, caring leaders," The Journal of Virtues \& Leadership 1, no. 1 (2010): 25-30, https://d1wqtxts1xzle7.cloudfront.net/45822855/Spears_Final.pdf?1463810771. 
keputusan-keputusannya adalah keputusan yang baik dan sempurna sebagaimana yang tertulis dalam Roma 12: 2. Ada lima aspek intuisi yang berbeda, yaitu pemrograman mental bawah sadar, nilai-nilai atau keputusan berbasis etika, keputusan berbasis pengalaman, keputusan yang diprakarsai pengaruh dan keputusan berbasis kognitif. Pemimpin dipengaruhi oleh spiritualitas, semua aspek ini dapat memainkan peran penting dalam setia keputusan. ${ }^{32}$ Karena itu dalam pembentukan sikap mental, pembaharuan budi dan etika perlu didasarkan pada firman Allah yang bermanfaat untuk mengajar, menyatakan kesalahan, memperbaiki kelakuan dan mendidik dalam kebenaran (2Tim. 3: 16).

Keempat, memerlukan pemahaman doktrin yang benar. Hasil wawancara di atas menyatakan bahwa saat para mahasiswa mengalami masalah dan dituntut untuk mengatasi masalah maka hal yang sangat mempengaruhi sikap dan keputusan mereka adalah pengajaran-pengajaran yang didapatkan dalam ruang kelas, diskusi-diskusi, percakapan dan ajaran para pembina membuat mereka dapat menyikapi masalah dengan cara pandang Allah. Perjanjian Lama mengajarkan tentang hikmat yang perlu dimiliki oleh seorang pemimpin dan Perjanjian Baru menyatakan bahwa pelayan Kristus di bumi juga meliputi pengajaran yang menyatakan tentang Allah dan kehendak-Nya, maka sebagai pelayan Kristus perlu diperlengkapi untuk memiliki wawasan pemikiran yang luas tentang kepemimpinan dan pemahaman yang kuat tentang doktrin-doktrin Alkitabiah. J. Knox Chamblin menuliskan bahwa pengenalan akan Allah membawa kepada suatu kesadaran terhadap kesetiaan kepada Kristus dan terus hidup dalam keserupaan kepada Kristus, menyadari panggilan untuk mengenakan

32 Brad Jackson, "The influence of religion-based workplace spirituality on business leaders' decision-making: An inter-faith study," June 2006Journal of Management \& Organization 12(1), 2006, https://doi.org/DOI: 10.5172/jmo.2006.12.1.23. 
kehidupan yang baru dan kekudusan sejati. ${ }^{33}$ Sehingga kehidupan sebagai seorang pemimpin dipengaruhi oleh doktrin untuk menjadi serupa dengan Kristus.

Kelima, perlu memberikan pengalaman-pengalaman bersama Tuhan. Hasil wawancara menyatakan bahwa saat kekurangan mereka belajar dari orang-orang di sekitarnya baik itu melalui adik tingkat mapun dosen yang mengajar. Permasalahan-permasalahan yang terjadi tidak membuat mereka mundur karena diajar untuk menggumulkannya di dalam Tuhan. Octavianus menuliskan pengalaman-pengalaman bersama dengan Tuhan tentang bagaimana harus taat kepada panggilan Tuhan, kerelaan menderita dan bagaimana pemeliharaan Tuhan serta peneguhan panggilan Tuhan dinyatakan-Nya dari pengalaman-pengalaman hidup. ${ }^{34}$ Membentuk Pemimpin yang melayani perlu membiarkan para mahasiswa menghadapi permasalahan hidup. Jatuh bangun mereka dalam kehidupan dan perjuangan mereka untuk setia kepada Kristus memperkaya pengalaman hidup sebagai pemimpin. Para pemimpin diajari untuk dapat menerima kegagalan, memaknai kegagalan sebagai sebuah pengajaran dan mengapresisai keberhasilan dengan sewajarnya. Pengalaman-pengalaman kehidupan membuat para pemimpin berempati dan peduli terhadap sesama atau terhadap orang-orang yang kelak akan dipimpin. Hal ini jelas telah diteladankan dengan sempurna saat Kristus melibatkan para murid menghadapi begitu banyak pergumulan dan tantangan, maupun saat memberikan teladan untuk menerima kegagalan maupun keberhasilan orang lain untuk maju.

Keenam, mengembangkan potensi-potensi yang ada. Hasil wawancara menyatakan bahwa para mahasiswa dilibatkan dalam berbagai macam pelayanan

33 J.Knox Chamblin, Paulus dan Diri, Ajaran Rasuli bagi keutuhan pribadi (Surabaya: Penerbit Momentum, 2008), $x$.

34 Petrus Octavianus, Hidupku Untuk Tuhan Dan Sesama (Batu: YPPII Batu, 2002), x. 
dan didikan yang memungkinkan mereka untuk mengembangkan potensi-potensi mereka. Dari yang tidak bisa mengajar menjadi bisa mengajar karena diberi kesempatan dan diarahkan untuk mengembangkan potensi. Firman Tuhan dalam Matius 25: 14-46 menyatakan bahwa setiap hamba akan diberikan oleh Tuhan berbagai macam talenta yang harus dikembangkan masing-masing sesuai dengan kemampuan dan hal ini akan dipertanggungjawabkan kepada Tuhan. Dalam jurnal Asia Pacific Journal of Advanced Business and Social Studies, Jannah mengobservasi bahwa kinerja seseorang sangat dipengaruhi oleh konsep-konsep religius maupun pengalaman spiritual seseorang. Selanjutnya Jannah mampu mengembangkan dan mempertanggungjawabkan potensi dengan sebaik-baiknya untuk menjadi seorang pemimpin. ${ }^{35}$ Talenta-talenta tersebut adalah kemampuankemampuan dan karunia-karunia rohani yang diberikan untuk kemajuan Kerajaan Allah. Para pemimpin perlu mengenali karunia masing-masing dan mengerjakannya sesuai dengan kemampuannya untuk memperluas kerajaan Allah.

Ketujuh, perlu mendapatkan kasih dan kepedulian. Hasil wawancara menyatakan bahwa kasih dan kepedulian dari bapak ibu asrama, bapak ibu dosen dan Pembina serta kakak-kakak tingkat membuat hati mereka dipenuhi oleh kasih, sehingga mereka terdorong untuk memberikan kasih yang sama kepada orangorang yang dilayaninya dan kepada sesamanya. Seorang pemimpin hamba mampu mempedulikan sesama dan sungguh mencintai Tuhan jika terlebih dahulu memperoleh kasih Tuhan. Dalam journal yang diterbitkan oleh Cambridge William Lillie menyatakan bahwa kasih Kristus yang telah dialami

35 Claudius Budi Santoso Syayyidah Maftuhatul Jannah, "The Impact Of Workplace Spirituality On Organizational Citizenship Behavior: The Roles Of Organizational Identification And Perceviced Organizational Support," Asia Pacific Journal of Advanced Business and Social Studies 3, no. 2 (2017): 1320. http://doi10.25275/apjabssv3i2bus2 
memungkinkan untuk mengasihi sesame dan mebuat tidak hidup bagi diri sendiri. Hanya tindakan dan penderitaan Yesus Kristus yang memungkinkan untuk memahami apa itu kasih. Kasih Tuhan kepada manusia itu trerefleksi dalam kasih sebagai ayah, kasih para sahabat dan kasih dari dan kepada lingkungan sekitar. ${ }^{36}$ Kasih itulah yang memulihkan hidup seseorang, kasih sejati dari Kristus juga diterima dari lingkungan.

Yesaya 49: 15-16 menyatakan bahwa Tuhan telah melukiskan orang-orang pilihan-Nya pada tembok-tembok-Nya dan Tuhan Yesus dalam kepemimpinan sangat peduli dengan pribadi-pribadi yang berjumpa dengan Dia, baik itu pemungut cukai, perempuan Samaria, orang lumpuh, orang buta, wanita yang kedapatan berzinah, anak-anak, Nikodemus dan sebagainya. Kepedulian Yesus kepada setiap individu menyentuh sampai bagian terdalam kehidupan seseorang dan membimbing hingga orang tersebut merdeka. Para calon pemimpin hamba perlu mendapatkan pelayanan seperti orang-orang yang dilayani Kristus dan mereka juga peduli terhadap orang-orang yang akan dipimpinnya.

Kedelapan, mengembangkan keahlian-keahlian. Wawancara di atas menyatakan bahwa para mahasiswa dapat meningkatkan kemampuan karena diajari dan difasilitasi dengan berbagai macam keterampilan seperti berkhotbah, menggunakan media IT dan melayani pastoral konseling. Para pemimpin hamba perlu menerima pelatihan ketrampilan dalam bidang-bidang yang dibutuhkan untuk memperlengkapi kemapuan memimpin, Mereka juga diajar untuk bisa kreatif dalam menyikapi situasi dengan cara bertanya maupun mendengar pendapat atau tanggapan orang lain dan dapat bekerja sama dengan tim. Serta

${ }^{36}$ William Lillie, "The Christian Conception of Love," Scottish Journal of Theology 12, no. 3 (2009), 
belajar untuk melatih kemampuan berkolaborasi dengan para pemimpin lain secara efektif, karena setiap pemimpin memiliki gaya kepemimpinan yang berbeda dan kemampuan dalam bidang yang berbeda. Para pemimpin hamba dilatih dalam sikap, gaya hidup dan keputusan-keputusannya dapat menginspirasi orang lain serta mempimpin orang lain menjadi lebih baik. Seorang pemimpin hamba perlu mengembangkan daya tahan dengan memiliki sistem pendukung yang baik, menjaga otak dan tubuh tetap aktif serta mengembangkan kesadaran diri. $^{37}$ Ketrampilan praktis dalam tekhnologi masa kini perlu dimiliki untuk mengikuti perkembangan zaman.

\section{KESIMPULAN}

Akhir dari tulisan ini dapat disimpulkan bahwa selain pemimpin itu dilahirkan, ternyata itu juga dapat dibentuk melalui sebuah pendampingan. Pola pendampingan yang dilakukan secara intensif akan membentuk seseorang menjadi pemimpin hamba seperti Kristus. Hal ini menjawab permasalahan STTE untuk kebutuhan hadirnya para pemimpin yang rendah hati, melayani dan memilki karakteristik seperti Tuhan Yesus yang dilayani. Pendampingan untuk membentuk pemimpin hamba memerlukan sebuah komitmen dari diri orang-orang yang sedang didampingi, terlebih juga menuntut kesetiaan dan dedikasi para pembimbing, mentor, pembina yang rela untuk menjadi teladan, kerelaan memberi hidup, ruang, waktu, materi, perhatian dan kasih serta pengajaranpengajaran yang harus diberikan secara tekun. Maka hal tersebut akan dipakai Tuhan untuk membentuk orang-orang yang Tuhan panggil menjadi para pemimpin hamba seperti Tuhan yang telah memanggil mereka untuk melayani.

${ }^{37}$ Charlie, " 5 ways to nurture your leadership skills," t.t. 


\section{DAFTAR PUSTAKA}

Aisiah, Selamat Tua, Rosana, Wince, dan Rani. Wawancara: Pemimpin Yang Melayani Dan Menjadi Teladan Bagi Orang Yang Dipimpinnya. Video Call, 30 Januari 2021.

Anne Cyril, Lesley. "Nurturing Servant Leaders In Religious Education: A Case Study Of The Church Educational System Of The Church Of Jesus Christ Of Latter-Day Saints In Aotearoa/New Zealand." Auckland University of Technology, 2006. https://core.ac.uk/download/pdf/56361157.pdf.

Benazo. Wawancara: Sebelum Dibentuk Di STTE Sebagian Besar Mahasiswa Tidak Memiliki Kemapuan Menjadi Pemimpin Yang Melayani. Sekolah Tinggi Theologia Ebenhaezer, 30 Januari 2021.

Benazo, Semangat Gea, dan Arnit Daeli. Wawancara: Sebelum Dibentuk Di STTE Sebagian Besar Mahasiswa Tidak Memiliki Kemapuan Menjadi Pemimpin Yang Melayani. Sekolah Tinggi Theologia Ebenhaezer, 30 Januari 2021.

Chamblin, J.Knox. Paulus dan Diri, Ajaran Rasuli bagi keutuhan pribadi. Surabaya: Penerbit Momentum, 2008.

Charlie. "5 ways to nurture your leadership skills," t.t.

Creswell, J.W. Research design: pendekatan kualitatif, kuantitatif, dan mixed. Jogyakarta: PT Pustaka Pelajar, 2010.

Cyril, Lesley Anne. "Nurturing Servant Leaders In Religious Education: A Case Study Of The Church Educational System Of The Church Of Jesus Christ Of Latter-Day Saints In Aotearoa/New Zealand." Auckland University of Technology, 2006. https://www.researchgate.net/publication/30040483_Nurturing_servant_le aders_in_religious_education

Fati. Wawancara: Sebelum Dibentuk Di STTE Sebagian Besar Mahasiswa Tidak Memiliki Kemapuan Menjadi Pemimpin Yang Melayani. Video Call, 30 Januari 2021.

Flanike, Forrest. "Is the Bible relevant to servant-leadership?" Journal of Applied Christian Leadership 1, no. 1 (2006): 32-39. https://digitalcommons.andrews.edu/cgi/viewcontent.cgi?article=1002\&co ntext=jacl.

Focht, Adam, dan Michael Ponton. "Identifying primary characteristics of servant leadership: Delphi study." International Journal of Leadership Studies 9, no. 1 (2015). https://citeseerx.ist.psu.edu/viewdoc/download?doi=10.1.1.675.4155\&rep $=$ rep $1 \&$ type $=$ pdf. 
Harefa, Febriaman Lalaziduhu. Wawancara: Evaluasi Dari Para Stakeholder Atau Lembaga Dimana Para Mahasiswa Melayani. Sekolah Tinggi Theologia Ebenhaezer, 2 Februari 2021.

Hilton, Andrew E. \& John H Walton. Survei Perjanjian Lama. Malang: Gandum Mas, 2000.

Jackson, Brad. "The influence of religion-based workplace spirituality on business leaders' decision-making: An inter-faith study." June 2006Journal of Management \& Organization 12(1), 2006. https://doi.org/DOI: 10.5172/jmo.2006.12.1.23.

Kuhl, Roland G. "What is Pastoral Leadership? A Review of the Relevant Literature on Approaches and Understandings of Pastoral Leadership at the Beginning of the 21stCentury." Grand Canyon University, 2005. https://www.academia.edu/11236608/ Lillie, William. "The Christian Conception of Love." Scottish Journal of Theology 12, no. 3 (2009).

Lizardy-Hajbi, Kristina. "Nurturing Leadership Development for the Now and the Next: A Denominational Perspective." Reflective Practice: Formation And Supervision In Ministry 38, no. 1 (2018): 25-38. https://journals.sfu.ca/rpfs/index.php/rpfs/article/view/515/498.

Lukito, Danar, Dedi Siboro, Rani, dan Leta. Wawancara Apakah bisa membentuk seorang pemimpin yang kuat melalui sebuah pendampingan bagi seorang yang secara genetik tidak dilahirkan dalam gen pemimpin? Sekolah Tinggi Theologia Ebenhaezer, 18 Desember 2019.

Mareti. Wawancara: Pengalaman Hidup Selama Dibentuk Di STTE. Video Call, 30 Januari 2021.

Margaretha, Meily. "Pengaruh Servant Leadership, Organizational Citizenship Behavior, Kecocokan Orang-Organisasi Serta Identifikasi Organisasi (Studi Pada Organisasi Kemahasiswaan Di Lingkungan Universitas Kristen Maranatha." Jurnal Manajemen Univ. Maranatha Vol.12, No (2012). https://doi.org/10.28932/jmm.v12i1.173

N, N. "Nurture." Www.oxfordlearnersdictionaries.com. Oxford Learners Dictionaries. $\quad$ Diakses $27 \quad$ April 2021. https://www.oxfordlearnersdictionaries.com/definition/english/nurture_1, $\% 20$ nurture, \%20t.t.

"Nurturing Leadership Qualities." Www.inspiring.uk.com. Inspiring $\begin{array}{lllll}\text { Bussines } & \text { performance, } & 9 & \text { Mei }\end{array}$ https://www.inspiring.uk.com/nurturing-leadership-qualities/.

Newton, Christopher J. "Towards a Theology of Servanthood." Phoenix, University of January (20016). 
https://www.researchgate.net/publication/303971273_Towards_a_Theolog y_of_Servanthood

Nsiah, Gabriel Kofi Boahen. "Leading as Jesus Led: Christ Models of Leadership." Open Journal of Leadership 02, no. 04 (2013): 103-5. https://doi.org/10.4236/oj1.2013.24016.

Octavianus, Petrus. Hidupku Untuk Tuhan Dan Sesama. Batu: YPPII Batu, 2002.

Petrus Octavianus. Alih Generasi dan kepemimpinan dalam garis Firman Allah. Batu, Jawa Timur: Petrus Octavianus Institute, t.t.

Rani. Wawancara: Belajar Peka Terhadap Kehendak Tuhan. Video Call, 30 Januari 2021.

Sibarani. Wawancara: Evaluasi Dari Para Stakeholder Atau Lembaga Dimana Para Mahasiswa Melayani. Pematang Siantar, 2 Februari 2021.

Simorangkir, Riris. Wawancara: Evaluasi Dari Para Stakeholder Atau Lembaga Dimana Para Mahasiswa Melayani. Bandung, 2 Januari 2021.

Spears, Larry C. "Character and servant leadership: Ten characteristics of effective, caring leaders." The Journal of Virtues \& Leadership 1, no. 1 (2010): $25-30$. https://d1wqtxts1xzle7.cloudfront.net/45822855/Spears_Final.pdf?146381 0771 .

Sudirman, Subhan Ajrin. "Pengaruh Spiritualitas Terhadap Servant Leadership Dan Kinerja Pimpinan." Journal Psikologi Islam Al-Qalb Vol 8, No (2017). https://doi.org/10.15548/alqalb.v8i2.878

Syayyidah Maftuhatul Jannah, Claudius Budi Santoso. "The Impact Of Workplace Spirituality On Organizational Citizenship Behavior: The Roles Of Organizational Identification And Perceviced Organizational Support." Asia Pacific Journal of Advanced Business and Social Studies 3, no. 2 (2017): 13-20. http://doi10.25275/apjabssv3i2bus2

Thompson, Robert S. "The perception of servant leadership characteristics and job satisfaction in a church-related college." Disertasi, Christian universities and colleges., 2015. http://scholars.indstate.edu/handle/10484/8123.

Wince, Mekar, Rani, dan Leta. Wawancara: Belajar Bermacam-macam Skill. Sekolah Tinggi Theologia Ebenhaezer, 30 Januari 2021.

Zaluchu, Sonny Eli. "Kepemimpinan Hamba (Servant Leadership): Sebuah Tipologi Kepemimpinan dalam Cara Pandang Kristen." Sonnyelizaluchu.wordpress.com. Sonny Eli Zaluchu, 18 Februari 2011. https://sonnyelizaluchu.wordpress.com/2011/02/18/kepemimpinanhamba/. 